\title{
Splice-site and Frameshift Mutations of $\beta$-Globin Gene Found in Thalassemia Carrier Screening in Yogyakarta Special Region, Indonesia
}

\author{
Niken Satuti Nur Handayani*, Nailil Husna, Gunawan Rahmil, Riris Anindya Ghifari, \\ Lily Widyawati, Indra Lesmana
}

Department of Tropical Biology, Faculty of Biology, Universitas Gadjah Mada, Jl. Teknika Selatan, Sekip Utara, Yogyakarta, Indonesia

${ }^{*}$ Corresponding author. E-mail: niken_satuti@ugm.ac.id

Received date: Sep 21, 2020; Revised date: Dec 23, 2020; Accepted date: Dec 30, 2020

\section{Abstract}

B ACKGROUND: $\beta$-thalassemia is an inherited blood disorder that relatively common in Southeast Asian countries. In Indonesia, it is estimated that 200,000 infants with thalassemia carrier born each year. Mutation causing $\beta$-thalassemia is highly varied and relatively specific in a population. This study aimed to identify the mutations responsible for $\beta$-thalassemia from Thalassemia Carrier Screening conducted in Yogyakarta Special Region. This information is beneficial for developing a strategic prevention program to control thalassemia in the region.

METHODS: Twenty-eight blood samples of haematologically suspected $\beta$-thalassemia from participant of thalassemia screening program in Yogyakarta Special Region were investigated for $\beta$-globin gene mutation by polymerase chain reaction-restriction fragment length polymorphism (PCR-RFLP), amplification refractory mutation system (ARMS) and DNA sequencing.

\section{Introduction}

$\beta$-thalassemia is defined as a quantitative defect in production of $\beta$-globin chains due to mutation on $\beta$-globin (HBB) gene, either total absence or marked reduction. It is a common inherited blood disorder that spread worldwide and found prevalently in some South Asian countries. $(1,2)$ In 2012, Indonesian Health Ministry estimated that 3,000 babies with thalassemia and 200,000 infant with thalassemia carrier born each year.(3) Despite the fact that
RESULTS: Our samples showed average $\mathrm{HbA} 2$ value of $5 \pm 0.81 \%$ and $\mathrm{HbF}$ value of $2 \pm 2.29 \%$. It showed eight abnormal erythrocyte morphologies dominated by hypochromia (96.4\%), cigar cell (85.7\%), and microcytosis (78.6\%). Our molecular investigation identified three splice-site mutations namely InterVening Sequence (IVS)$1-5(\mathrm{G}>\mathrm{C})(71.4 \%)$, IVS-1-2 $(\mathrm{T}>\mathrm{C})(7.1 \%)$, and IVS-1-1 $(\mathrm{G}>\mathrm{T})(3.6 \%)$, two frameshift mutations that are CD35 (-C) $(10.7 \%)$ and $\mathrm{CD} 8 / 9(+\mathrm{G})(3.6 \%)$, and a missense mutation of CD6 (GAG>GTG) (3.6\%).

CONCLUSION: Our study concluded on a high prevalence of IVS-1-5 (G>C) mutation in Yogyakarta Special Region. This mutation information is significant for developing a strategic prevention program to control thalassemia in the region, for example for developing a rapid molecular test for future screening program.

KEYWORDS: $\beta$-Globin gene, thalassemia, screening, carrier, mutation, Yogyakarta

Indones Biomed J. 2021; 13(1): 55-60 thalassemia carriers can live a healthy life, the patients with $\beta$-thalassemia major require lifelong therapy for survival, namely blood transfusion and iron chelation.(4) Carrier screening combined with genetic counselling is an effective prevention program to control the number of new birth with thalassemia major.(5-7)

$\beta$-thalassemia is highly varied at the molecular level with more than 300 mutations were reported. Furthermore, $\beta$-thalassaemia mutations are relatively population specific meaning certain region might carry a few common mutations.(4) In Indonesia, mutation spectrum 
for $\beta$-thalassaemia has been reported in East Kalimantan and West Java.(8,9) However, study on $\beta$-thalassemia in Yogyakarta Special Region is limited to its haematological analysis (10), while the molecular study is absent. Therefore, through this study, we aim to report the mutations responsible for $\beta$-thalassemia from thalassemia carrier screening conducted in Yogyakarta Special Region. This mutation information is essential for developing a strategic prevention program to control thalassemia in the region.

\section{Methods}

\section{Participants and Ethical Consideration}

Ethical clearance for this study was granted by the Medical and Health Research Ethics Committee (MHREC), Faculty of Medicine, Public Health and Nursing, Universitas Gadjah Mada/Dr. Sardjito General Hospital (Ref. No.: KE/ FK/1320/EC/2019). Venous blood samples from unrelated healthy individuals who voluntarily participating in thalassemia carrier screening organized by Indonesian Association of Parents of Children with Thalassemia (APCT) Yogyakarta, the Indonesia Thalassemia Foundation (ITF) and in collaboration with Faculty of Biology, Universitas Gadjah Mada were obtained and performed for its complete blood count, peripheral blood smear and $\mathrm{Hb}$ analysis by high-performance liquid chromatography (HPLC). The inclusion criteria are samples with $\mathrm{HbA} 2$ value between $3.5 \%$ and $13 \%$. Informed consents were received from each volunteer prior to blood collection with detailed explanation. The confidentiality of collected and retrieved data are ensured.

\section{Molecular Detection for $\beta$-globin Gene Mutation}

Twenty-eight samples were complied with the inclusion criteria and were intentionally recruited for underdoing molecular test. The genomic DNA was isolated using Blood/Cell DNA Mini Kit (Geneaid, Taipei, Taiwan). Splice-site mutations causing $\beta$-thalassemia were detected using the amplification refractory mutation system (ARMS) employing primer sets A-D for InterVening Sequence (IVS)-1-5 (G>C) and IVS-1-1 (G>C) (11), and polymerase chain reaction-restriction fragment length polymorphism (PCR-RFLP) using primer sets TLF62028-TLR62320 and restriction endonuclease Cac81 for IVS-1-5 (G>C) and IVS-1-2 (T>C) (Table 1). $(8,12)$

Other mutation was investigated using DNA sequencing. DNA fragment of about 704-bp covering exon 1 , intron 1 and exon 2 of $\beta$-globin gene was amplified using standard PCR. The reaction employing primer 1 and primer 5 described in our previous study (13) was performed in the same condition. Then, DNA fragments were sequenced using Sanger methods by DNA Sequencing Services ( $1^{\text {st }}$ BASE, Selangor, Malaysia). DNA sequences were analysed using GeneStudio Software (GeneStudio, Inc., Georgia, US) and aligned with the template sequence from GenBank NCBI (RefSeq: NC_000011.10) using ClustalW (EMBL-EBI, Cambridgeshire, UK) to determine the mutation.

\section{Results}

$\mathrm{Hb}$ analysis and erythrocyte morphology of the samples were presented in Table 2. The average HbA2 value was $5 \pm 0.81 \%$ ranging from $3.5 \%$ to $6.1 \%$, whereas for $\mathrm{HbF}$ was

Table 1. Name and sequence of the primers.

\begin{tabular}{|c|c|c|c|c|c|}
\hline Methods & Mutation & Primer Name & Primer Sequence & Product Length & Reference \\
\hline \multirow[t]{9}{*}{ ARMS } & \multirow[t]{2}{*}{ Control Primer } & $\mathrm{D}$ & Forward 5' CAATGTATCATGCCTCTTTGCACC 3' & \multirow{2}{*}{ 861-bp (D-C pair) } & \multirow[t]{9}{*}{11} \\
\hline & & $\mathrm{C}$ & Reverse 5' AGTCAAGGCTGAGAGATGCAGGA 3' & & \\
\hline & \multirow[t]{3}{*}{ IVS-1-5 (G > C) } & $\mathrm{B}$ & Forward 5' ACCTCACCCTGTGGAGCCAC 3' & \multirow{3}{*}{$\begin{array}{l}\text { 286-bp (B-N1 pair } \\
\text { or B-M1 pair) }\end{array}$} & \\
\hline & & N1 & Reverse 5' CTCCTTAAACCTGTCTTGTAACCTTGTTAC 3' & & \\
\hline & & M1 & Reverse 5' CTCCTTAAACCTGTCTTGTAACCTTGTTAG 3' & & \\
\hline & \multirow[t]{4}{*}{ IVS-1-1 (G > T) } & $\mathrm{N} 2$ & Forward 5' GATGAAGTTGGTGAGGCCCTGGGTAGG 3' & \multirow{4}{*}{$\begin{array}{l}\text { 455-bp (N2-A pair) } \\
\text { 281-bp (B-M2 pair) }\end{array}$} & \\
\hline & & A & Reverse 5' CCCCTTCCTATGACATGAACTTAA 3' & & \\
\hline & & $\mathrm{B}$ & Forward 5' ACCTCACCCTGTGGAGCCAC 3' & & \\
\hline & & M2 & Reverse 5' TTAAACCTGTCTTGTAACCTTGATACGAAA 3' & & \\
\hline \multirow[t]{2}{*}{ PCR-RFLP } & IVS-1-5 (G > C) & TLF62028 & Forward 5' ACCTCACCCTGTGGAGCCAC 3' & \multirow[t]{2}{*}{ 293-bp } & \multirow[t]{2}{*}{12} \\
\hline & and IVS-1-1 $(\mathrm{G}>\mathrm{T})$ & TLR62320 & Reverse 5' CTATTGGTCTCCTTAAACCTGTCTTGTAACCTTGCTA 3' & & \\
\hline \multirow[t]{2}{*}{ DNA sequencing } & \multirow{2}{*}{$\begin{array}{l}\mathrm{CD} 35(-\mathrm{C}), \mathrm{CD} 8 / 9(+\mathrm{G}) \text {, } \\
\text { and CD6 }(\mathrm{GAG}>\mathrm{GTG})\end{array}$} & $1 \mathrm{~F}$ & 5' CCAAGGACAGGTACGGCTGTCATC 3' & \multirow[t]{2}{*}{ 704-bp } & \multirow[t]{2}{*}{13} \\
\hline & & $5 \mathrm{R}$ & 5' CСТTCCTATGACATGAACTTAACCAT 3' & & \\
\hline
\end{tabular}


Table 2. Haemoglobin analysis and erythrocyte morphology on peripheral smear.

\begin{tabular}{lccc}
\hline \multicolumn{1}{c}{ Parameter } & Mean \pm SD & Range & n (\%) \\
\hline Haemoglobin analysis & & & \\
HbA2, \% & $5 \pm 0.81$ & $2.6-6.1$ & \\
HbF, \% & $2 \pm 2.29$ & $0.6-10.8$ & \\
\hline Erythrocyte morphology & & & \\
Hypochromia & & $27(98.4)$ \\
Microcytosis & & $22(78.6)$ \\
Cigar cell & & $24(85.7)$ \\
Fragmented cell & & $21(75.0)$ \\
Target cell & & $17(60.7)$ \\
Tear drop cell & & $7(25.0)$ \\
Basophilic stippling & & $4(14.3)$ \\
Microspherocyte & & $3(10.7)$ \\
Blister cell & & $1(3.6)$ \\
Polychromasia & & $1(3.6)$ \\
Burr cell & & $1(3.6)$ \\
\hline
\end{tabular}

$2 \pm 2.29 \%$ ranging from $0.6 \%$ to $10.8 \%$. The peripheral smear data showed eight abnormal erythrocyte morphologies dominated by hypochromia (98.4\%), cigar cell (85.7\%), and microcytosis $(78.6 \%)$.

From the molecular investigation of the 28 samples, three mutation groups were obtained. They were splice-site, frameshift and missense mutations. Splice-site mutation consisted of three alleles namely, IVS-1-5 (G>C) as the

A

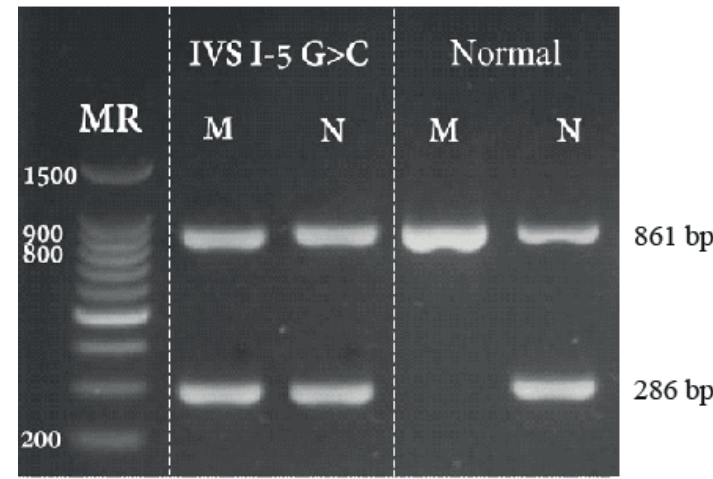

B

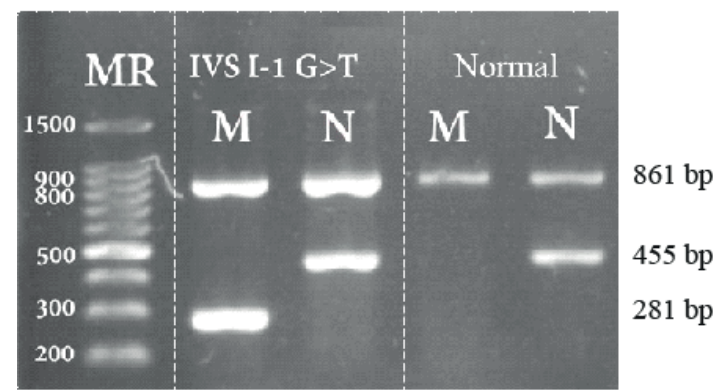

Table 3. Mutant alleles of $\beta$-globin gene in $\beta$-thalassemia carrier.

\begin{tabular}{ccc}
\hline \multicolumn{2}{c}{ Mutant Allele } & n (\%) \\
\cline { 1 - 2 } Mutation & HGVS-nomenclature & \\
Splice site & & \\
IVS-1-5 $(\mathrm{G}>\mathrm{C})$ & HBB: c.92+5 G $>\mathrm{C}$ & $20(71.4)$ \\
IVS-1-2 $(\mathrm{T}>\mathrm{C})$ & HBB: c.92+2 T $>\mathrm{C}$ & $2(7.1)$ \\
IVS-1-1 $(\mathrm{G}>\mathrm{T})$ & HBB: c.92+1 G $>\mathrm{T}$ & $1(3.6)$ \\
\hline Frameshift & & \\
CD35 $(-\mathrm{C})$ & HBB: c. 110 delC & $3(10.7)$ \\
CD8/9 $(+\mathrm{G})$ & HBB: c.27_28insG & $1(3.6)$ \\
\hline Missense & & \\
CD6 $(\mathrm{GAG}>\mathrm{GTG})$ & HBB: c.20A $>\mathrm{T}$ & $1(3.6)$ \\
\hline
\end{tabular}

most abundant (71.4\%), IVS-1-2 (T>C) (7.1\%), and IVS-1$1(\mathrm{G}>\mathrm{T})(3.6 \%)$. Frameshift mutations contained CD35 (-C) $(10.7 \%)$ and $\mathrm{CD} 8 / 9(+\mathrm{G})(3.6 \%)$. Lastly, missense mutation with only CD6 (GAG>GTG) (3.6\%) was also found. The results are outlined in Table 3.

The results of molecular investigation can be seen in Figure 1. In ARMS results, 861-bp fragment was the control reaction, IVS-1-5 was confirmed when 286-bp fragment is present in reaction with mutant primers (Figure 1A), whereas IVS-1-1 was confirmed with the presence of 281bp fragment with mutant primers (Figure 1B). PCR-RFLP can detect two mutations in a single digest reaction. In the

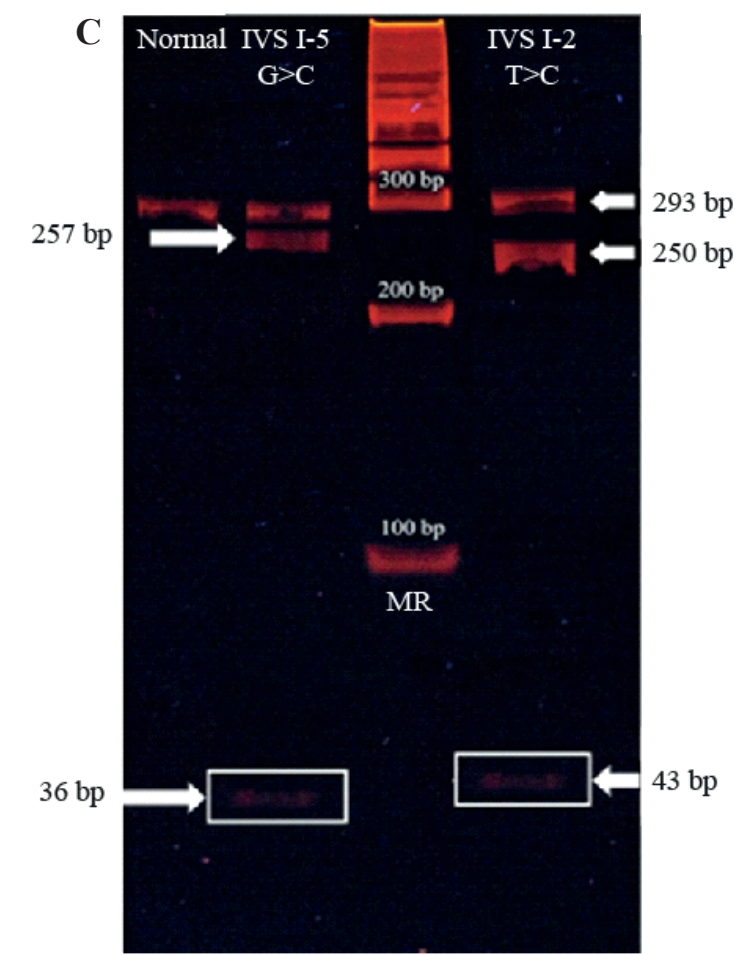

Figure 1. Electrophoregram of splice site mutations of $\boldsymbol{\beta}$-globin gene. A: ARMS result for IVS-1-5 (G>C); B: ARMS result for IVS-1-1 $(\mathrm{G}>\mathrm{T})$; C: PCR-RFLP result for IVS-1-5 $(\mathrm{G}>\mathrm{C})$ and IVS-1-2 $(\mathrm{T}>\mathrm{C})$. M: ARMS reaction using mutant primers, N: ARMS reaction using normal/control primers, MR: DNA marker or ladder. 
presence of IVS-1-2, Cac8I restriction enzyme cut the initial 293-bp fragment into 43-bp and 250-bp, whereas in IVS-1-5 allele, it resulted 36-bp and 257-bp (Figure 1C). The presence of 293-bp showed that the sample was heterozygous thus it still has normal allele that unrecognized by the enzyme. DNA sequencing results was presented in Figure 2. It is clearly showed the frameshift implication in CD35 (-C) and CD8/9 (+G) allele. As for CD6 (GAG>GTG), it showed nucleotide polymorphism showing heterozygous state of arginine and thymine.

Figure 3 showed $\beta$-globin chain alignment of the first 70 amino acids as the result of frameshift and missense mutations. Missense mutation of CD6 (GAG>GTG) clearly showed amino acid change from glutamic acid (E) to valine (V) at codon 6. Frameshift mutation of CD35 (-C) showed amino acid shifting starting from codon 36 and resulting a stop codon at supposedly codon 60 . As for CD8/9 $(+G)$, the shifting started at codon 9 and resulting a stop codon at supposedly codon 22. Therefore, CD35 (-C) and CD8/9 $(+\mathrm{G})$ produced a short $\beta$-globin chain with 59 and 22 sequences, respectively.

\section{Discussion}

This study was conducted to identify mutations responsible for $\beta$-thalassemia trait in the carrier screening participants. Prior to molecular test, subject was predicted to be $\beta$-thalassemia carrier based on the haematological parameter. We employed $\mathrm{HbA} 2$ value between $3.5 \%$ to $13 \%$ amplified with the presence of abnormal erythrocyte variant especially microcytosis, hypochromia, and anisocytosis. $(4,14)$ Red blood cell count can also be used to predict thalassemia carrier using erythrocyte indices such as Mentzer index, Shine and Lal index (S\&L), and Green and King index (G\&K), though its sensitivity were heavily affected by the presence of iron deficiency.(15)

The average value of $\mathrm{HbA} 2$ in this study was $5 \pm 0.81 \%$ in which close to a similar study in Malaysia (5.14 $\pm 0.55 \%)$. (16) Erythrocyte morphological change is very prominent in patient, while in carrier is less severe.(4) This study reported four erythrocyte variants with more than 75\% appearance in carrier subject namely, microcytosis, hypochromia, cigar cell and fragmented cell (Table 2). In similar study involving 33 carrier subjects in Austria, some erythrocyte variants were also appeared, namely target cells $100 \%$, ovalocytes $(96.9 \%)$, dacryocytes $27(81.8 \%)$, stomatocytes $(81.8 \%)$ and elliptocytes (75.8\%).(17)

This study reported six $\beta$-globin gene mutations with one splice-site mutation showing clear dominancy namely IVS-1-5 (G>C) (71.4\%) (Table 3). This result was complimenting studies on mutation spectrum in $\beta$-thalassemia patients in Indonesia. In a hospital in West Java, this mutation was detected in $77.1 \%$ patients.(8) Other splice-site mutations namely IVS-1-2 (T>C) and IVS-1-1 $(\mathrm{G}>\mathrm{T})$ might show a few prevalence, but it carried a similar threat to inherit a thalassemia major case. A study in East Kalimantan reported IVS-1-2 (T>C) (25.8\%) and IVS$1-1(\mathrm{G}>\mathrm{T})(9.7 \%)$ in patients as a result of co-inheritance with CD6 (GAG>GTG) or HbE trait.(9) In term of gene
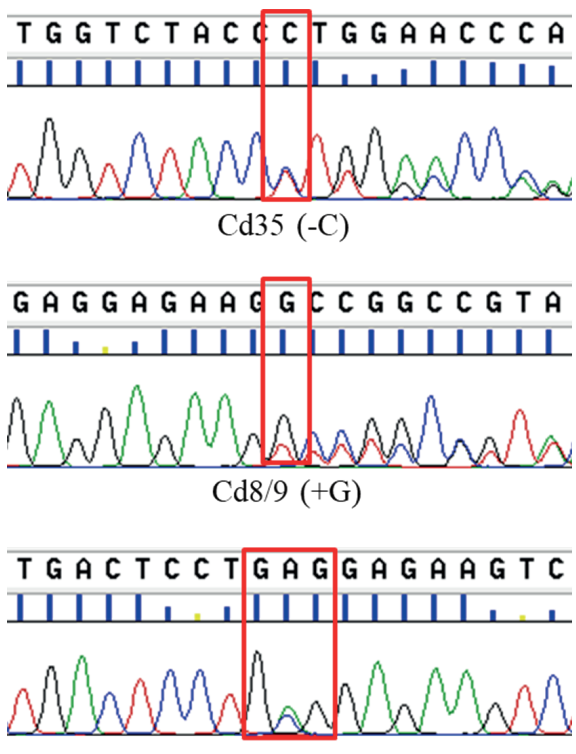

Cd6 GAG $>$ GTG
$\overline{T G G T G G T C T \overline{T A C D C T T G G A}}$
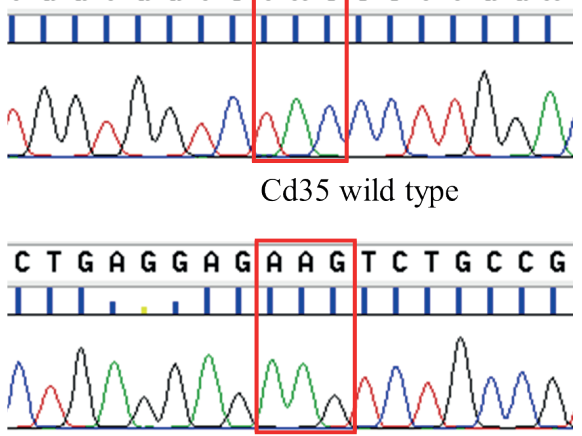

Cd8 wild type

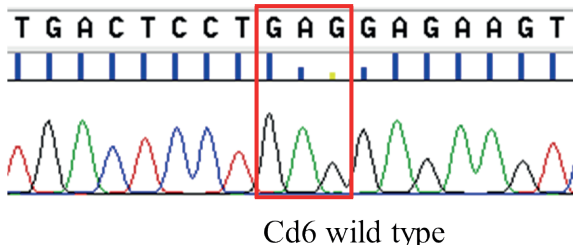

Figure 2. Chromatogram of frameshift and missense mutations of $\beta$-globin gene and the corresponding wild types. 

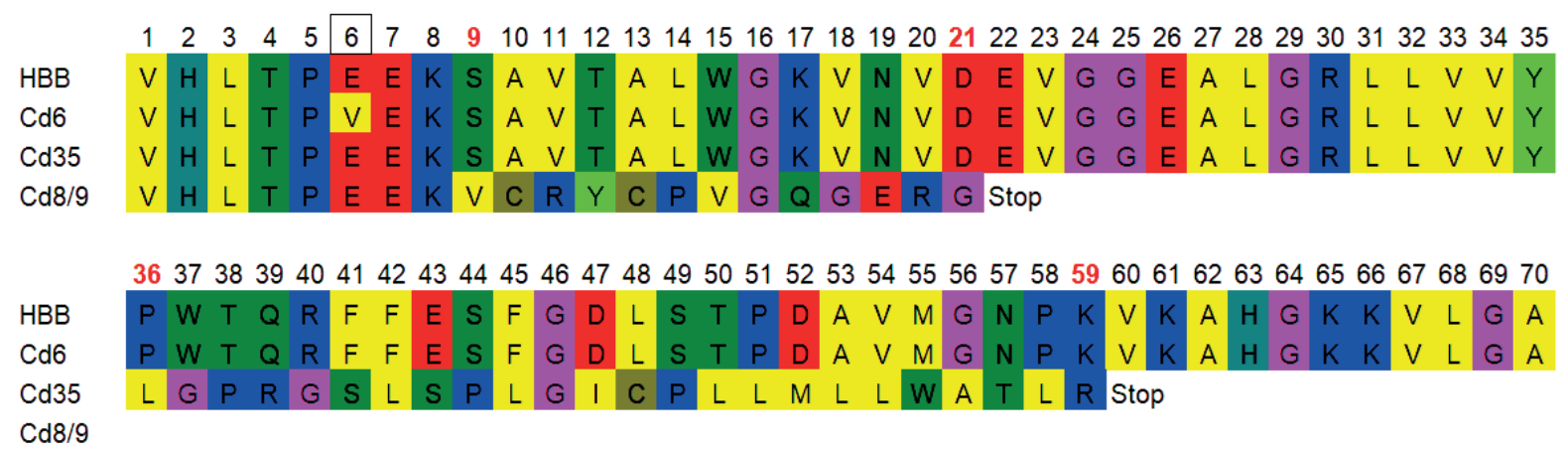

Figure 3. Amino acid alignment of $\boldsymbol{\beta}$-globin chain as the result of frameshift and missense mutations. Upper: frameshift of $\mathrm{Cd} 8 / 9$ $(+\mathrm{G})$ mutation started at codon 9 until codon 21; lower: frameshift of Cd35 (-C) mutation started at codon 36 until codon 59 (see the red numbers), and missense mutation is shown in codon 6 (number in square).

expression, these three mutations gave significant effect on RNA splicing and mRNA stability. IVS-1-1 (G>T) and IVS-1-2 $(\mathrm{T}>\mathrm{C})$ disrupted 5' splice junction consensus "GT-AG", while IVS-1-5 (G>C) activated cryptic resulting a probability of expressing abnormal mRNAs.(18) The abnormal and unstable mRNA might trigger nonsensemediated mRNA decay (NMD) pathway or proteolysis mechanism.(19)

Two frameshift mutations were found in this study. CD35 (-C) was found in $\beta$-thalassemia carriers in Yogyakarta (20), and $\beta$-thalassemia patients (16.1\%) which also a result of co-inheritance with $\mathrm{HbE}$ trait in Samarinda (9). Whereas, CD8/9 $(+\mathrm{G})$ was found in a $\beta$-thalassemia carrier in Bandung.(21) These mutations lead to formation of a stop codon or called premature translation-termination codons (PTCs), resulting a very short protein. The presence of PTC can trigger the destruction mechanism of mRNA namely NMD pathway. A study determined codon 24-87 as the sensitive region of PTCs that activated NMD pathway. (19) Since our DNA analysis identified PTCs of CD35 (-C) in codon 60 and $\mathrm{CD} 8 / 9(+\mathrm{G})$ in codon (22), NMD decay is likely occurred only in CD35 (-C) allele. Whereas in CD8/9 $(+\mathrm{G})$ allele, a short protein of about 21 amino acids will still be expressed (Figure 3).

This study also found CD6 (GAG>GTG), a missense mutation causing substitution of glutamic acid to valine at codon 6 (Figure 3). This mutation is responsible for causing sickle cell trait (SCT) by forming an abnormal haemoglobin variant called $\mathrm{HbS}$. Asymptomatic state of SCT has $\mathrm{HbA} 2$ value of $3.6 \%$, therefore it is often misdiagnosed as $\beta$-thalassemia carrier. However, the gold standard in diagnosing SCT is the presence $\mathrm{HbS}$ (at least $38 \%$ ) in $\mathrm{Hb}$ analysis (11), which was not observed in this study.

To identify the mutations, this study employed PCRbased techniques namely ARMS and PCR-RFLP and DNA sequencing. ARMS and PCR-RFLP are modified PCR techniques that still required a post-PCR procedure namely gel or polyacrylamide electrophoresis (Figure 1). Though effective for detecting rare mutation, DNA sequencing is costly. Overall, these procedures are inefficient and highpriced to be applied in a nationwide screening program. A rapid molecular detection was desired to screen specific mutation that commonly found in the areas. The examples of this rapid detection were TaqMan genotyping to detect four $\beta$-thalassemia mutations and Tm-shift real-time polymerase chain reaction (Tm-shift qPCR) and high-resolution melting analysis (HRMA) that detect mutation on HbE trait. $(13,22)$ Our finding on high frequency of IVS-1-5 $(\mathrm{G}>\mathrm{C})$ mutation contributed on the importance of implementing a rapid molecular test for this mutation especially to be applied in future screening program in Yogyakarta and its surrounding area.

\section{Conclusion}

Our study reported mutation spectrum from thalassemia carrier screening conducted in Yogyakarta Special Region. We found six $\beta$-globin gene mutations with one mutation showed a clear dominancy, IVS-1-5 $(\mathrm{G}>\mathrm{C})$. Since a rapid molecular test on the IVS-1-5 (G>C) mutation is already available, our finding supports its implementation as the confirmatory test in future screening program in the region.

\section{Acknowledgements}

Authors express gratitude to Indonesian Association of Parents of Children with Thalassemia (APCT) Yogyakarta and the Indonesia Thalassemia Foundation (ITF) for conducting the screening and Ministry of Research and Technology for funding support. 


\section{Authors Contribution}

NSNH conceived and designed the research, supervised the research, and proofread the paper. NH performed sequencing analysis and wrote the paper with input from all authors. GN collected data by performing ARMS. RAG and LW collected data by performing PCR-RFLP. IL collected data by performing DNA sequencing.

\section{References}

1. Forget BG, Franklin Bunn H. Classification of the disorders of hemoglobin. Cold Spring Harb Perspect Med. 2013; 3: a011684. doi: 10.1101/cshperspect.a011684.

2. Fucharoen S, Winichagoon P. Haemoglobinopathies in Southeast Asia. Indian J Med Res. 2011; 134: 498-506.

3. Surilena. Peranan Relasi keluarga pada psikopatologi remaja penderita talasemia. Damianus J Med. 2014; 13: 137-47.

4. Galanello R, Origa R. Beta-thalassemia. Orphanet J Rare Dis. 2010; 5: 11. doi: 10.1186/1750-1172-5-11.

5. Noor FA, Sultana N, Bhuyan GS, Islam MDT, Hossain M, Sarker SK, et al. Nationwide carrier detection and molecular characterization of $\beta$-thalassemia and hemoglobin e variants in Bangladeshi population. Orphanet J Rare Dis. 2020; 15: 1-12. doi: 10.1186/s13023-0201294-z.

6. Haghpanah S, Nasirabadi S, Rahimi N, Faramarzi H, Karimi M. Sociocultural challenges of beta-thalassaemia major birth in carriers of beta-thalassaemia in Iran. J Med Screen. 2012; 19: 109-11.

7. Dewanto JB, Tansah H, Dewi SP, Napitu H, Panigoro R, Sahiratmadja E. Increased knowledge of thalassemia promotes early carrier status examination among medical students. Universa Med. 2016; 34: 220. doi: 10.18051/univmed.2015.v34.220-228.

8. Maskoen AM, Rahayu NS, Reniarti L, Susanah S, Laksono B, Fauziah $\mathrm{PN}$, et al. Mutation spectrum of $\beta$-globin gene in thalassemia patients at Hasan Sadikin Hospital - West Java Indonesia. Cell Mol Biol. 2017; 63: 22-4.

9. Susanto ZA, Siswandari W, Rujito L. Cd60 (GTG $>$ GAG) $/ \mathrm{Hb}$ Cagliari mutation was found in scanning of $\beta$-thalassemia alleles from patients of East Kalimantan, Indonesia. Mol Genet Metab Reports. 2020; 22: 100550. doi: 10.1016/j.ymgmr.2019.100550.

10. Husna N, Al Arif A, Putri C, Leonard E, Handayani NSN. Prevalence and distribution of thalassemia trait screening. J Med Sci. 2017; 49: 106-13.

11. Old J, Traeger-Synodinos J, Galanello R, Petrou M, Angastiniotis M. Prevention of Thalassaemias and other Haemoglobin Disorders. 2nd Edition. Nicosia: Thalassaemia International Federation; 2013.

12. Pramoonjago P, Harahap A, Taufani RA, Setianingsih I, Marzuki S. Rapid screening for the most common $\beta$ thalassaemia mutations in south east Asia by PCR based restriction fragment length polymorphism analysis (PCR-RFLP). J Med Genet. 1999; 36: 937-8.

13. Al Arif A, An-Nizamiya AD, Putri C, Nashrurrokhman M, Husna N, Mulyati, et al. Comparison between three molecular diagnostics for the identification of heterozygous hemoglobin E. Pakistan J Biol Sci. 2020; 23: 17-26.

14. Danjou F, Anni F, Galanello R. Beta-thalassemia: From genotype to phenotype. Haematologica. 2011; 96(11): 1573-5.

15. Surjawan Y, Tan HL, Setiabudy RD, Rositawati W. Early screening of hemoglobinopathy in Indonesia using erythrocyte indices. Indones Biomed J. 2017; 9: 99-105.

16. Hafiza A, Malisa MY, Khirotdin RDAT, Azlin I, Azma Z, Thong MCK, et al. $\mathrm{HbA} 2$ levels in normal, $\beta$-thalassaemia and haemoglobin $\mathrm{E}$ carriers by capillary electrophoresis. Malays J Pathol. 2012; 34: 161-4.

17. Körber C, Wölfler A, Neubauer M, Robier C. Red blood cell morphology in patients with $\beta$-thalassemia minor. J Lab Med. 2017; 41: 49-52.

18. Thein SL. Molecular basis of $\beta$ thalassemia and potential therapeutic targets. Blood Cells Mol Dis. 2018; 70: 54-65.

19. Peixeiro I, Silva AL, Romão L. Control of human $\beta$-globin mRNA stability and its impact on beta-thalassemia phenotype. Haematologica. 2011; 96: 905-13.

20. Handayani NSN, Purwanto R. CD35 (DEL C) frameshift mutation in exon 2 of $\beta$-globin gene on $\beta$-thalassemia carriers. Biomed Eng (NY). 2015; 1: 19-23.

21. Maskoen AM, Reniarti L, Sahiratmadja E, Sisca J, Effendi SH. Shine $\&$ Lal index as a predictor for early detection of $\beta$-thalassemia carriers in a limited resource area in Bandung, Indonesia. BMC Med Genet. 2019; 20: 1-6. doi:10.1186/s12881-019-0868-x.

22. Kho SL, Chua KH, George E, Tan JAMA. High throughput molecular confirmation of $\beta$-thalassemia mutations using novel TaqMan probes. Sensors (Switzerland). 2013; 13: 2506-14. 